\title{
Differences in colorectal cancer surgery outcomes in Ser- bia: hospitals in organized colorectal cancer screening and other hospitals
}

\author{
Razlike u ishodima operisanih od kolorektalnog karcinoma \\ u Srbiji: bolnice u organizovanom skriningu kolorektalnog \\ karcinoma i ostale bolnice
}

\author{
Dusica Bankovic Lazarevic ${ }^{1,2}$, Verica Jovanovic ${ }^{1}$, \\ Biljana Mijovic ${ }^{3}$, Jelena Brcanski ${ }^{1}$, Marina Jelic ${ }^{1}$, \\ Danijela Radojicic ${ }^{4}$ \\ 1. Institute of Public Health of Serbia "Dr Milan Jovanović Batut", Belgrade, Serbia \\ 2. Faculty of Dental Medicine, Pančevo, Serbia \\ 3. University of East Sarajevo, Faculty of Medicine, Foča, Republic of Srpska, \\ Bosnia and Herzegovina \\ 4. General Hospital, Cuprija, Serbia \\ RECEIVED 05.03.2021. \\ ACCEPTED 08.04.2021.
}

\section{ABSTRACT}

Objective. The aim of this study was to compare mortality of patients after colorectal cancer surgery between hospitals in Serbia, which performed organized colorectal cancer screening and those which did not.

Methods. The database included all patients who underwent surgery for colorectal cancer after the introduction of organized colorectal cancer screening Program in Serbia, in 2014- 2015. The target group were patients 50-74 years old in the colorectal screening program, and the data was compared to the age-matched group from hospitals which did not perform the program logistic regression.

Results. The was used to determine the significance of the differences in the observed variables, and the predictors of mortality after colorectal cancer surgery.

Results.The 3631 patients were included in this study. The majority of them were operated due to the rectal cancer 2111 (58\%), while 1062 (29.2\%) were operated due to the colon cancer. Postoperative survival was significantly better in the target group in organized screening program $(p<0.001$; $\mathrm{OR}=0.46 ; 95 \%$ CI $0.33-0.62$ ).

There was a significant difference between patients who underwent surgery for colorectal cancer localized in the left colon, compared to the patients with localization in the right colon $(p<0.001)$. The mortality after the surgery of colorectal cancer $(4.7 \%)$ was followed by high comorbidity of cardiovascular diseases (24\%).

Conclusion. Patients included in the organized colorectal cancer screening have lower postoperative mortality than these not included. This indicates the necessity for further work on organized colorectal cancer screening, in order to reduce postoperative and overall mortality.

Key words: colorectal neoplasms; surgical procedures, operative; mortality; early detection of cancer; Serbia.

\author{
Dušica Banković Lazarevićc ${ }^{1,2}$, Verica Jovanović ${ }^{1}$, \\ Biljana Mijović3 ${ }^{3}$ Jelena Brcanski ${ }^{1}$, Marina Jelić ${ }^{1}$, \\ Danijela Radojicic ${ }^{4}$

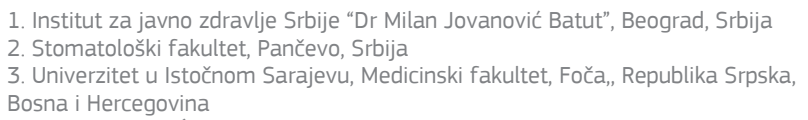 \\ PRIMLJEN 05.03.2021. \\ PRIHVAĆEN 08.04.2021.
}

\section{APSTRAKT}

Cilj. Cilj rada je bio da se analizira smrtnost pacijenata operisanih od kolorektalnog karcinoma u bolnicama u organizovanom skriningu kolorektalnog karcinoma i bolnicama van skrininga u Srbiji.

Metode. Korišćena je baza pacijenata operisanih od kolorektalnog karcinoma posle uvođenja Programa organizovanog skrininga iz svih bolnica u Srbiji, u periodu 2014 - 2015. godine. Operisani pacijenti su analizirani u odnosu na ciljnu grupu iz organizovanog skrininga 50 - 74 godine, $i$ poređeni su sa operisanim pacijentima iste starosne grupe $u$ bolnicama van skrininga. Za utvrđivanje značajnosti razlike u posmatranim varijablama i prediktora smrtnog ishoda posle operacije kolorektalnog carcinoma, korišćena je univarijantna logistička regresija.

Rezultati. Od 3631 pacijenta operisanog od kolorektalnog karcinoma, najviše je hospitalizovano zbog karcinoma rektuma (2112 ili 58,2\%), a manje zbog karcinoma kolona (1063 ili 29,2\%). Postoperativno preživljavanje je bilo značajno bolje u ciljnoj grupi u organizovanom skriningu $(\mathrm{p}<0,001 ; \mathrm{OR}=0,46 ; 95 \%$ CI $0,33-0,62)$. Postojala je visoko statistički značajna razlika pacijenata operisanih od kolorektalnog carcinoma, lokalizovanog u levom kolonu, $\mathrm{u}$ odnosu na operisane sa lokalizacijom u desnom kolonu $(\mathrm{p}<0,001)$. Smrtni ishod posle operacije kolorektalnog karcinoma $(4,7 \%)$ praćen je povišenim komorbiditetom od kardiovaskularnih bolesti (24\%).

Zaključak. Pacijenti koji su uključeni u organizovani skrining kolorektalnog karcinoma imaju manji rizik za umiranje posle operacije kolorektalnog karcinoma od pacijenata koji nisu uključeni u program. Ovo nalaže dalji rad na organizovanom skriningu kolorektalnog karcinoma radi smanjivanja operativnog i opšteg mortaliteta.

Ključne reči: kolorektalne neoplazme, hirurški zahvati, operativni mortalitet, rano otkrivanje raka, Srbija. 


\section{INTRODUCTION}

Colorectal cancer is a significant public health problem due to thehigh incidence and high mortality rate both in the world population and in Serbia. It affects yearly over 1.23 million of people in the world, which represents $10 \%$ of all malignancies. Every year, 600.000 people die of colorectal cancer worldwide. ${ }^{1}$ In Serbia, colorectal cancer is the second most common cancer in bothmen and women, and regarding mortality, it is the second cause of cancer death in men and the third in women. Every year, around 4000 new cases are registered in Serbia, and 2600 of them die as a consequence of the disease. We believe that majority of these cases could be avoided through an effective screening program $^{2}$.

With the aim of lowering the incidence and mortality of colorectal cancer in Serbia, the program of organized colorectal cancer screening of decentralized type was introduced in 2013, with quality assurance and evaluation, including the target population of men and women (50 to 74 years of age) that would be tested with immuno-chemical iFOBT(FTTs) test, for early detection of colorectal cancer. All cases with positive iFOB test were referred to colonoscopy, which allows early detection and possible prevention of colorectal cancer. ${ }^{3,4}$

Colorectal cancer usually requires intensive and multimodal treatment, with a high risk of complications and a high cost of this service, from diagnostic workup to all other aspects of health care. ${ }^{1,5}$ Surgical treatment of colorectal cancer is stillthe most important curative option and the postoperative mortality should be minimized. ${ }^{6}$ Even with significant advances in surgical and multimodal treatment, almost $50 \%$ of patients with symptomatic colorectal cancer die due to metastatic disease. ${ }^{5}$ Significant differences in mortality after colorectal cancer surgery exist in geographical regions and different hospitals in many countries, but it is not quite clear which are the predictors of the mortality. ${ }^{7-9}$ After introduction of the Program of organized colorectal cancer screening in Serbia, in 2014 -2015, it was important to establish geographical and hospital variability in relation to postoperative mortality of colorectal cancer as well as the characteristics of hospitalization that more often lead to the lethal outcome. ${ }^{7}$ It is not certain which factors contribute to an increased risk of death and complications after surgical treatment in colorectal cancer surgery. ${ }^{8}$

The aim of this study was to establish differences in characteristics of patients who underwent surgery for colorectal cancer in Serbia within the period of 2014-2015, according to demographic features and types of hospitals and their involvement in screening. We also aimed to determine predictors of the post-operative mortality in hospitals that participated in organized colorectal cancer screening compared to hospitals that did not, particularly in relation to the way of detection of colorectal cancer (screening or otherwise).

\section{PATIENTS AND METHODS}

Data source-sample

This was a retrospective cohort study. The source of data was the database of the Institute of Public Health of Serbia "Dr Milan Jovanovic Batut". This database includes all patients in Serbia, hospitalized due to colorectal cancer who underwent surgery, since all hospitals must provide and send this data to the central database. This research encompassed the sample of all 3631 hospitalized patients who underwent surgery forcolorectal cancer in the period 2014 -2015 in all health care institutions of the secondary (general hospitals) and tertiary health carelevel (clinics/teaching hospitals). A subgroup of patients operated in hospitals in 30 municipalities in Serbia which conducted the organized colorectal cancer screening, was also established.

Criteria for inclusion into the study were: patients who underwentsurgery for colorectal cancer in the period 2014 - 2015, with one of the diagnoses according to International Classification of Disease (ICD-10): C18.0 Neoplasma malignum caeci; C18.1 Neoplasma malignum appendicis vermifomis; C18.2 Neoplasma malignum coli ascendentis; C18.3 Neoplasma malignum flexurae coli hepaticae; C18.4 Neoplasma malignum coli transversi; C18.5 Neoplasma malignum flexurae coli lienalis; C18.6 Neoplasma malignum coli descendentis; C18.7 Neoplasma malignum coli sigmoidis; C18.8 Neoplasma malignum coli; C18.9 Neoplasma malignum coli, non specificatum; C19 Neoplasma malignum juncturae coli rectosigmoidis; C20 Neoplasma malignum recti; C21. Neoplasma malignum ani et canalis analis.

\section{Variables}

The main dependent variable in this study was mortality after colorectal cancer surgery. Two groups of patients were created. The first group included patients from districts and hospitals where organized colorectal cancer screening was performed (screening group). This group included 13 general hospitals and 6 clinics. The second group included patients from districts and hospitals where organized colorectal cancer screening was not performed (non-screening group). This group included 17 general hospitals and 6 clinics. The data regarding colorectal cancer screening, both organized and opportunistic, were available for every patient and were separately recorded.

Regarding to permanent residency of the patient and the statistical regions of Serbia, the following groups were created: Belgrade, Vojvodina, Central and West Serbia, South and Southeast Serbia and Kosovo. The screening group included patients who underwent surgery for colorectal cancer, 50 to 74 years old, while non-screening group included patients ofall ages. 


\section{Statistical analysis}

The methods of descriptive and interferential statistics were applied in this research. For the estimate of the difference between the observed groups chi square and t-test were used. Univariate logistic regression was used for the establishment of the predictors of the mortality after colorectal cancer surgery.

\section{RESULTS}

In 2014 and 2015 in all Serbian public hospitals and clinics/teaching hospitals founded by the Ministry of Health of Serbia (40 general hospitals and 12 clinics) a total of 3631 patients, with average age of $66 \pm 10.5$ years were operateddue to colorectal cancer. The age span was from 18 to 93 years, $60.2 \%$ (2186 patients) were males, and 39.8\% (1455 patients) were females, shown in table 1 . Distribution of patients concerning the patients' gender did not show statistically significant difference in frequency among patients operated in hospitals that participated in organized colorectal cancer screening and in those who did not $(\mathrm{p}>0.05)$. A total of 171 patients died after surgery, 118 (63.1\%) were males and 63 (36.9\%) were females. The differences in mortality according to gender were not statistically significant $(\mathrm{p}=0.41)$.

Table 1. Patients underwent surgery for colorectal cancer in hospitals in organized screening and non-screening hospitals.

\begin{tabular}{|c|c|c|c|c|}
\hline $\begin{array}{l}\text { Basic data about patents } \\
\text { underwent surgery for } \\
\text { colorectal cancer }\end{array}$ & $\begin{array}{l}\text { Patients in } \\
\text { screening } \\
\text { hospitals N } \\
\text { (\%) }\end{array}$ & $\begin{array}{l}\text { Patients in } \\
\text { non-screen- } \\
\text { ing hospital } \\
\mathrm{N}(\%)\end{array}$ & Total N (\%) & $\begin{array}{c}\mathrm{p} \\
\text { value }\end{array}$ \\
\hline Gender & 2508 & 1123 & $3631(100)$ & \\
\hline Male & $1501(59.8)$ & $685(61.0)$ & $2186(60.2)$ & \\
\hline Female & $1007(40.2)$ & $438(39.0)$ & $1445(39.8)$ & \\
\hline $\begin{array}{l}\text { Year of the colorectal } \\
\text { surgery }\end{array}$ & 2508 & 1123 & $3631(100)$ & $0.002+$ \\
\hline 2014 & $1207(48.1)$ & 477 (42.5) & $1648(46.4)$ & \\
\hline 2015 & 1301 (51.9) & $646(57.5)$ & 1947 (53.6) & \\
\hline $\begin{array}{l}\text { Level of health care- sur- } \\
\text { gery done }\end{array}$ & 2508 & 1123 & $3631(100)$ & $0.006+$ \\
\hline Secondary level & $966(38.5)$ & $487(43.4)$ & $1453(40.0)$ & \\
\hline Tertiary level & $1542(61.5)$ & $636(56.6)$ & $2178(60.0)$ & \\
\hline Hospital discharge & 2508 & 1123 & $3631(100)$ & $0.000+$ \\
\hline Discharge home & 2348 (94.3) & $1002(89.2)$ & 3366 (92.7) & \\
\hline $\begin{array}{l}\text { Discharge to another } \\
\text { hospital }\end{array}$ & $3(0.1)$ & $7(0.6)$ & $10(0.3)$ & \\
\hline $\begin{array}{l}\text { Discharge to another } \\
\text { hospital for short time } \\
\text { hospitalization }\end{array}$ & $13(0.5)$ & $16(1.4)$ & $29(0.8)$ & \\
\hline $\begin{array}{l}\text { Discharge against medi- } \\
\text { cal advice }\end{array}$ & $2(0.1)$ & $5(0.4)$ & $7(0.2)$ & \\
\hline Statistical discharge & $19(0.8)$ & $29(2.6)$ & $48(1.3)$ & \\
\hline Deceased & $107(4.3)$ & $64(5.7)$ & $171(4.7)$ & \\
\hline $\begin{array}{l}\text { Diagnosis of the underly- } \\
\text { ing cause for hospitaliza- } \\
\text { tion }\end{array}$ & 2508 & 1123 & $3631(100)$ & $0.000 \dagger$ \\
\hline \multicolumn{5}{|l|}{ Right colon } \\
\hline C18.0 & 207 (8.3) & $102(9.1)$ & $309(8.5)$ & \\
\hline C18.1 & $15(0.6)$ & $5(0.4)$ & $20(0.6)$ & \\
\hline C18.2 & $279(11.1)$ & 122 (10.9) & $401(11.0)$ & \\
\hline C18.3 & $114(4.5)$ & $45(4.0)$ & $159(4.4)$ & \\
\hline C18.4 & $104(4.1)$ & $70(6.2)$ & $174(4.8)$ & \\
\hline \multicolumn{5}{|l|}{ Left colon } \\
\hline C19 & $231(9.2)$ & $110(9.8)$ & $341(9.4)$ & \\
\hline $\mathrm{C} 20$ & $1510(60.2)$ & $602(53.6)$ & $2112(58.2)$ & \\
\hline C21.0 & $7(0.3)$ & $11(1)$ & $18(0.5)$ & \\
\hline C21.1 & $12(0.5)$ & $6(0.5)$ & $18(0.5)$ & \\
\hline $\mathrm{C} 21.8$ & 29(1.2) & $50(4.5)$ & $79(2.2)$ & \\
\hline $\begin{array}{l}\text { Age group enveloped by } \\
\text { colorectal cancer screening }\end{array}$ & 2508 & 1123 & $3631(100)$ & $0.001 \dagger$ \\
\hline $50-74$ years & $1839(73.3)$ & $764(68)$ & $2603(71.7)$ & \\
\hline Other & $669(26.7)$ & $359(32)$ & $\begin{array}{l}1028( \\
28.3)\end{array}$ & \\
\hline $\begin{array}{l}\text { Patients according to the } \\
\text { permanent residency in } \\
\text { Region Serbia * }\end{array}$ & 2376 & 1109 & $3485(100)$ & $0.000+$ \\
\hline Belgrade & $700(29.5)$ & $130(11.7)$ & $830(23.8)$ & \\
\hline Vojvodina & $479(20.2)$ & $524(47.2)$ & $1003(28.8)$ & \\
\hline Central and West Serbia & $740(31.1)$ & $239(21.6)$ & $979(28.1)$ & \\
\hline $\begin{array}{l}\text { South and Southeast } \\
\text { Serbia }\end{array}$ & $433(18.2)$ & $213(19.2)$ & $646(18.5)$ & \\
\hline Kosovo & $24(1)$ & $3(0.2)$ & $27(0.8)$ & \\
\hline
\end{tabular}

* Patients according to the regions in which they have a registered legal domicile, were analyzed based on the statistical regions in Serbia and do not account for the 146 patients whose residence is unknown. $\dagger \mathrm{p}<0.001$ 
In the screening group there were 1501 males (59.8\%) and 1007 females $(40.2 \%)$, while in the non-screening group among a total of 1123 patients, there were 685 males (61\%) and 428 females (39\%) (Table 1; Figure 1). Average hospitalstay in the screening group was 15.8 days, compared to 15.7 days in the non-screening group. These differences were not statistically significant $(\mathrm{p}=0.840)$. Among all 2508 patients in the screening group, 966 (38.5\%) were operated in the secondary level health institutions (general hospitals), while 1542 (61.5\%) were operated in the tertiary level health institutions (clinics/teaching hospitals) (Table 1). Cumulative mortality rate was $4.7 \%$ (171 patients out of 3631 operated). The mortality in the screening group was 107 (62.5\%), and $64(37.5 \%)$ in the non-screening group. These differences were not statistically significant $(\mathrm{p}=0.060)$. The most frequent cancer localization in the left colon were: C20 Neoplasm malignum recti (58.2\%) and C19 Neoplasma malignum juncturae colirectosigmoidis, (9.4\%). In patients with localization of cancer in the right colon, the most frequent was the cancer of the caecum C18.0 (8.5\%), followed by the cancer of the ascending colon C18.2 (11\%), which is shown in table 1 and figure 1.

Surgery was much more frequent in patients with left sided cancers. Among 2508 patients operated in hospitals that were practicing colorectal cancer screening, 1839 (73.3\%) belonged to the target population of 50 - 75 years, while in the hospitals that were not in the screening, the target population was represented with $68 \%$. In the group of patients that belongs to the target population of the organized colorectal cancer screening, 87 out of 2481 patients (3.5\%) have died, and in the group of other ages 84 out of 1066 patients $(7.8 \%)$ died. These differences were statistically highly significant $(\mathrm{p}<0.001)$.

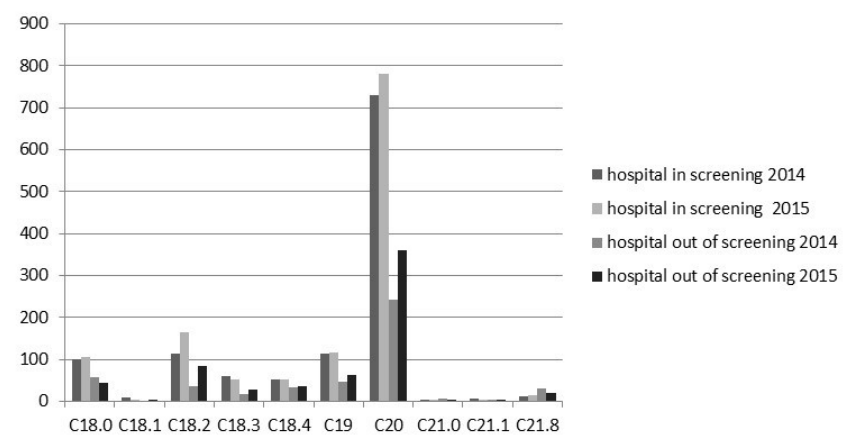

Figure 1. Distribution of the patients who underwent surgery for colorectal cancer related to diagnosis, participation in organized colorectal cancer screening and the year of surgery.

From the 3631 patients who underwent surgery for colorectal cancer in Serbia during the observed period within 2014 - 2015, 2508 (69\%) of all ages were operated in hospitals and clinics that participated in the organized colorectal cancer screening (1207 patients in 2014, and 1301 patient in 2015), which is shown on figure 1.

The connection between mortality of patients who underwent surgery for colorectal cancer and the level of health care, gender, screening and the region was assessed by univariate logistic regression (Table 2).

Table 2. Predictors of the death outcome after colorectal cancer surgery, univariate logistic regression.

\begin{tabular}{|l|c|c|c|c|c|}
\hline Predictors & $\mathrm{B}$ & $\mathrm{SE}$ & $\mathrm{p}$ & $\mathrm{OR}$ & $95 \% \mathrm{Cl}$ \\
\hline $\begin{array}{l}\text { Tertiary level of health } \\
\text { care/secondary level }\end{array}$ & 0.56 & 0.15 & 0.000 & 1.75 & $1.28-2.38$ \\
\hline $\begin{array}{l}\text { Population from } 50 \text { to } \\
74 \text { years of age }\end{array}$ & -0.77 & 0.15 & 0.000 & 0.46 & $0.33-0.62$ \\
\hline $\begin{array}{l}\text { Operation done in } \\
\text { hospital that is not in } \\
\text { screening program }\end{array}$ & 0.30 & 0.16 & 0.060 & 1.35 & $0.98-1.86$ \\
\hline $\begin{array}{l}\text { Operated patient was } \\
\text { not colorectal cancer } \\
\text { detected in screening } \\
\text { program }\end{array}$ & 0.50 & 0.16 & 0.02 & 1.65 & $1.20-2.28$ \\
\hline
\end{tabular}

B-coefficient; SE - standard error; p- value; OR- odds ratio; 95\% CIconfidence interval

According to this data, surgery at the tertiary level health care institution carried a higher risk of death compared to the surgery performed at the secondary level of health care $(\mathrm{p}<0.001 ; \mathrm{OR}=1.75 ; 95 \% \mathrm{CI} 1.28-2.38)$. There were no differences in mortality rates regarding the place of residence. Surgery performed in the hospitals that participated in organized colorectal cancer screening were not linked with the greater risk of dying $(\mathrm{p}=0.060)$. Patients in whom colorectal cancer was detected without the organized screening program were 1.65 times more likely to die, compared to those in whom colorectal cancer was detected in the organized screening program $(\mathrm{p}=0.02 ; \mathrm{OR}=1.65 ; 95 \% \mathrm{CI}$ 1.20-2.28). There was a highly statistically significant difference in frequency of cancer of the left colon compared to the localization in the right colon $(\mathrm{p}<0.001)$. Cancer of the right colon is most frequent in Vojvodina (35.7\%) compare to anther regions, which is shown on the table 3.

Table 3. Differences in distribution of the basic cause of hospitalization of patients underwent surgery for colorectal cancer in the various regions of Serbia

\begin{tabular}{|c|c|c|c|c|}
\hline \multirow[b]{2}{*}{ Region - Serbia } & \multicolumn{3}{|c|}{ Patients underwent colon cancer surgery } & \multirow[b]{2}{*}{$p$-value } \\
\hline & $\begin{array}{l}\text { Right N (\%) } \\
\text { Transverse, } \\
\text { ascending, } \\
\text { cecum }\end{array}$ & $\begin{array}{l}\text { Left N (\%) } \\
\text { Rectum, } \\
\text { sigmoid, } \\
\text { descending }\end{array}$ & Total N (\%) & \\
\hline Belgrade & $277(33.4)$ & $553(66.6)$ & $830(100)$ & \multirow{6}{*}{$0.000^{*}$} \\
\hline Vojvodina & $358(35.7)$ & $645(64.3)$ & $1003(100)$ & \\
\hline $\begin{array}{l}\text { Central and } \\
\text { West Serbia }\end{array}$ & 289(29.5) & $690(70.5)$ & $979(100)$ & \\
\hline $\begin{array}{l}\text { South and } \\
\text { Souteast Serbia }\end{array}$ & 103(15.9) & $543(84.1)$ & $646(100)$ & \\
\hline Kosovo & $4(14.8)$ & $23(85.2)$ & $27(100)$ & \\
\hline Total & $1031(29.6)$ & 2454(70.4) & $3485(100)$ & \\
\hline
\end{tabular}


There was no statistically significant difference in cause of death related to the age group ( $p>0.05$ ) (Table 4). A total of 226 patients were operated as emergent cases due to complications of colorectal cancer, which represents $6.4 \%$ of all operated patients. Seventy-five patients were operated due to peritonitis (K.65), and 151 due to ileus (K.56 and K.91).

Table 4. Causes of death of patients underwent surgery for colorectal cancer according to the age groups.

\begin{tabular}{|c|c|c|c|c|c|c|}
\hline \multirow[b]{2}{*}{ 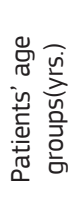 } & \multicolumn{6}{|c|}{ Cause of death } \\
\hline & 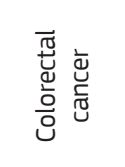 & 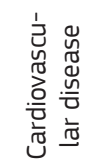 & 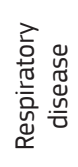 & 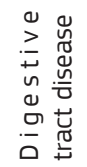 & 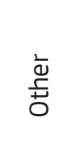 & $\begin{array}{l}\vec{\pi} \\
\stackrel{0}{0} \\
\stackrel{0}{0}\end{array}$ \\
\hline $1-30$ & $2(100)$ & $0(0)$ & $0(0)$ & $0(0)$ & $0(0)$ & $2(1.2)$ \\
\hline $31-50$ & $4(80.0)$ & $1(20.0)$ & $0(0)$ & $0(0)$ & $0(0)$ & $5(2.9)$ \\
\hline $51-74$ & $57(62.6)$ & 29(31.9) & 0 & 0 & $5(5.5)$ & $91(53.2)$ \\
\hline $75+$ & $57(78.1)$ & $11(15.1)$ & $2(2.7)$ & $2(2.7)$ & $1(1.4)$ & $73(42.7)$ \\
\hline Total & $120(70.2)$ & $41(24.0)$ & $2(1.2)$ & $2(1.2)$ & $6(3.5)$ & $171(100)$ \\
\hline
\end{tabular}

\section{DISCUSSION}

In the examined sample of patients who underwent surgery for colorectal cancer 108 males (63.1\%) and 63 females (36.9\%) died, but these differences were statistically not significant $(\mathrm{p}=0.41)$. This is not in accordance to the European studies, which showed higher postoperative mortality in males. ${ }^{10,7}$ On the other hand, the study performed in Hong Kong, on the smaller sample, also showed no difference in mortality regarding to the gender. ${ }^{11}$

Patients in our study had higher risk of dying if they were operated in health care institutions of the tertiary level $(\mathrm{p}<0.001 ; \mathrm{OR}=1.75 ; 95 \%$ CI $1.28-2.38)$ compared to the institutions of the secondary level. There were also some variations in mortality rates between the regions, though they were not statistically significant. In research conducted on patients undergoing surgery for colorectal cancer in Holland, France and England, differences in mortality rates were found in relation to the type of the health care institution and the region where patients belonged. ${ }^{7-10}$

A higher postoperative mortality in health care institutions of the tertiary level in our country can be explained by the fact that those institutions hospitalize patient swith advanced disease, where more advanced and complex procedures should be performed. In some studies, it was also suggested that the differences in types of hospitals might be of importance regarding complication and mortality rates after colorectal cancer surgery. ${ }^{7,12}$ Postoperative mortality registered in this study was $4.7 \%$ and is in accordance with other study involving 25591 patients in 92 hospitals in Holland, where the postoperative mortality varied from $0 \%$ to $8.8 \% .^{11}$
Belonging to the target group for organized colorectal cancer screening program was found to be protective regarding the postoperative mortality, which emphasizes the need for successful screening program and early detection of colorectal cancer $(\mathrm{p}<0.001)$. There were variations concerning the postoperative mortality according to the policy of hospitals regarding colorectal cancer screening, but those differences were statistically not significant. This can be explained by the fact that aside from the patients' colorectal cancer discovered by the screening, there were also those who were diagnosed without screening, which means that the greater territorial participation in screening will be needed, as well as better uptake to screening, in order to better estimate these differences. However, in our study patients who were diagnosed with colorectal cancer on a common way were dying postoperatively 1.65 times more often than the patients discovered through the screening program. This can be explained by the fact that the later patients were discovered with colorectal cancer in the earlier phases of the illness, which definitely pertains to the lengthening of their life span and improvement of the quality of their lives.

In numerous studies regarding mortality after colorectal cancer surgery, patients over 80 years old had the largest incidence of mortalityand higher comorbidity of cardiovascular and pulmonary diseases. ${ }^{10-14}$ In this study, there was no significant difference in mortality between different age groups, although the higher mortality was found in the age group of 50-74 years in comparison to other. The highest mortality was recorded in patients older than 75 years (78.1\%) and mortality because of the comorbidity of cardiovascular illnesses was in this study at the level of $24 \%$, which is in concordance with other studies in this area. ${ }^{15}$ The mortality rate recorded in this study was probably influenced by the fact that $6.7 \%$ of patients were operated as emergent cases due to the peritonitis or ileus. It is well known that mortality of urgent colorectal operations is much higher compared to elective surgery and varies from $15-25 \% .{ }^{16,17}$

There is no doubt that the numerous factors that contribute to the postoperative mortality need to be taken into the consideration in the future research. Some used scoring systems in order to predict more accurately postoperative mortality. ${ }^{18,19}$ Mortality after operation of colorectal cancer varies from $1-10.2 \%$. Great variations between the countries are influenced by many factors like the quality of health care system and the data collection which is still not standardized and because there is no heterogeneity in the research of this kind..$^{20,21}$

In conclusion, patients who are included in the organized screening of colorectal cancer have a lower risk of mortality after colorectal cancer surgery, than patients who are not included in the screening program. This mandates further work on the organized screening with the aim of early detection of colorectal cancer, in order to lessen operative and overall mortality. 


\section{REFERENCES}

1. Kuipers EJ, Rösch T, Bretthauer M. Colorectal cancer screening - optimizing current strategies and new directions. Nat Rev Clin Oncol 2013; 10: 130-42.

2. Banković Lazarević D, Krivokapić Z, Barišić G, Jovanović V, Ilić D, Veljković M. Organized colorectal cancer screening in Serbia-the first round within 2013-2014. Vojnosanit Pregl 2016; 78: 360-8.

3. Regulation on the National Programe on early detection of colorectal cancer. Official Gazette of the Republic of Serbia. 2013; No73. Belgrade: Official Gazette, 2013.

4. Garborg K, Holme O, Loberg M, Kalager M, Adami $\mathrm{HO}$, Bretthauer M. Current status of screening for colorectal cancer. Ann Oncol 2013; 24: 1963-72.

5. Pox CP. Controversies in colorectal cancer screening. Digestion 2014; 89: 274-81.

6. van Eeghen EE, den Boer FC, Loffeld RJ. Thirty days post-operative mortality after surgery for colorectal cancer: a descriptive study. J Gastrointest Oncol 2015; 6: 613-7.

7. Schootman M, Lian M, Pruitt SL, et al. Hospital and geographic variability in two colorectal cancer surgery outcomes: complications and mortality after complications. Ann Surg Oncol 2014; 21: 2659-66.

8. Ghaferi AA, Dimick JB. Variation in mortality after high-risk cancer surgery: failure to rescue. Surg Oncol Clin N Am 2012; 21:389-95.

9. Panis Y, Maggiori L, Caranhac G, Bretagnol F, Vicaut E. Mortality after colorectal cancer surgery: a French survey of more than 84,000 patients. Ann Surg 2011; 254:738-43.

10. Morris EJ, Taylor EF, Thomas JD, et al. Thirty-day postoperative mortality after colorectal cancer surgery in England. Gut 2011; 60:806-13.

11. Henneman D, van Bommel AC, Snijders A, et al. Ranking and rankability of hospital postoperative mortality rates in colorectal cancer surgery. Ann Surg 2014; 259:8449.

12. Rogers SO Jr, Wolf RE, Zaslavsky AM, Wright WE, Ayanian JZ. Relation of surgeon and hospital volume to processes and outcomes of colorectal cancer surgery. Ann Surg 2006; 244:1003-11.
13. Kim YW, Kim IY. Factors associated with postoperative complications and 1-year mortality after surgery for colorectal cancer in octogenarians and nonagenarians. Clin Interv Aging 2016; 11:689-97.

14. De Vries S, Jeffe DB, Davidson NO, Deshpande AD, Schootman M. Postoperative 30-day mortality in patients undergoing surgery for colorectal cancer: development of a prognostic model using administrative claims data. Cancer Causes Control 2014; 25:1503-12.

15. Dekker J, van den Broek C, Bastiaannet E, van de Geest L, Tollenaar R, Liefers G. Importance of the first postoperative year in the prognosis of elderly colorectal cancer patients. Ann Surg Oncol 2011; 18:1533-9.

16. Maartense S, Vrancken Peeters MP, Spaander PJ, Breslau PJ. Mortality after colon surgery: the value of a mortality registration system. Dig Surg 2003; 20:316-20.

17. Smothers L, Hynan L, Fleming J, Turnage R, Simmang C, Anthony T. Emergency surgery for colon carcinoma. Dis Colon Rectum 2003; 46:24-30.

18. Poon JT, Chan B, Law WL. Evaluation of P-POSSUM in surgery for obstruction colorectal cancer and correlation of the predicted mortality with different surgical options. Dis Colon Rectum 2005; 48:493-8.

19. Richards CH, Leitch FE, Horgan PG, McMillan DC. A systematic review of POSSUM and its related models as predictors of post-operative mortality and morbidity in patients undergoing surgery for colorectal cancer. J Gastrointest Surg 2010; 14:1511-20.

20. Ren L, Upadhyay AM, Wang L, Li L, Lu J, Fu W. Mortality rate prediction by Physiological and Operative Severity Score for the Enumeration of Mortality and Morbidity (POSSUM), Portsmouth POSSUM and Colorectal POSSUM and the development of new scoring systems in Chinese colorectal cancer patients. Am J Surg 2009; 198:31-8.

21. Teloken PE, Spilsbury K, Platell C; BCCA Operations Committee. Analysis of mortality in colorectal surgery in the Bi-National Colorectal Cancer Audit. ANZ J Surg 2016; 86:454-8. 